\title{
RESEARCHPAPER
}

\section{Identification of vibrio species from various water samples of Bareilly, using multiplex PCR}

\author{
ANGELIEN MASSEY AND AMIT ALEXANDER CHARAN \\ Department of Molecular and Cellular Engineering, Jacob School of Biotechnology and Bioengineering, Sam \\ Higginbottom Institute of Agriculture, Technology and Sciences, ALLAHABAD (U.P.) INDIA \\ Email : angelien.massey@gmail.com
}

Article Info : Received : 28.04.2016; Revised : 23.08.2016; Accepted : 12.09 .2016

The purpose of this study was to investigate the prevalence of Human pathogenic vibrio species in water bodies of Bareilly, U.P. using the traditional culture and multiplex PCR methods. Vibrio species are very much prevalent in water bodies of tropical region. The study was conducted on 25 various water samples collected from rivers and ponds of Bareilly, U.P. For this, species specific primers were designed targeting the toxgene of the five pathogenic species. Confirmation was done using multiplex PCR technique for rapid detection of the five selected pathogenic species including V. cholera, V.alginolyticus, V. parahaemolyticus, V. mimicus and V. vulnificus. Out of the five targeted species three were present i.e. V. cholera, V. alginolyticus, V. parahaemolyticus. Water is essential to life, but many people do not have access to clean and safe drinking water and many die of waterborne bacterial infections. In this review a general characterization of the most important bacterial diseases transmitted through water like cholera is present.

Key words : TCBS, Water samples, Vibrio cholerae

How to cite this paper : Massey, Angelien and Charan, Amit Alexander (2016). Identification of vibrio species from various water samples of Bareilly, using multiplex PCR. Asian J. Bio. Sci., 11 (2) : 281-283.DOI : 10.15740/HAS/AJBS/11.2/281-283. 